\title{
ECG Replicates at Baseline Indicator
}

National Cancer Institute

\section{Source}

National Cancer Institute. ECG Replicates at Baseline Indicator. NCI Thesaurus. Code

C119565.

An indication as to whether replicate ECGs for time points during the baseline portion of the study were included. 